\title{
Growth, governance and corruption in Bangladesh: a re-assessment
}

Article

Accepted Version

Asadullah, M. N. and Chakravorty, N. N. T. (2019) Growth, governance and corruption in Bangladesh: a re-assessment. Third World Quarterly, 40 (5). pp. 947-956. ISSN 1360-2241 doi: https://doi.org/10.1080/01436597.2019.1599854 Available at https://centaur.reading.ac.uk/84160/

It is advisable to refer to the publisher's version if you intend to cite from the work. See Guidance on citing.

To link to this article DOI: http://dx.doi.org/10.1080/01436597.2019.1599854

Publisher: Taylor \& Francis

All outputs in CentAUR are protected by Intellectual Property Rights law, including copyright law. Copyright and IPR is retained by the creators or other copyright holders. Terms and conditions for use of this material are defined in the End User Agreement.

\section{www.reading.ac.uk/centaur}

\section{CentAUR}

Central Archive at the University of Reading

Reading's research outputs online 


\title{
Growth, Governance and Corruption in Bangladesh: A Re-assessment
}

\author{
M Niaz Asadullah ${ }^{\text {abcde }}$ \\ N N TARUN CHAKRAVORTY ${ }^{\mathrm{f}}$ \\ ${ }^{\mathrm{a}}$ Faculty of Economics and Administration, University of Malaya, Malaysia \\ ${ }^{b}$ Department of Economics, University of Reading, UK \\ ${ }^{\mathrm{c}}$ Centre on Skills, Knowledge and Organisational Performance, University of Oxford, UK \\ IZA Institute of Labor Economics, Germany

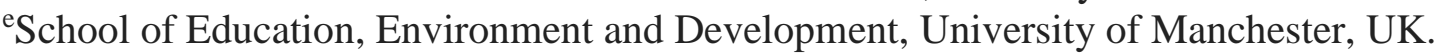 \\ ${ }^{\mathrm{f}}$ Siberian Federal University, Russia \\ Corresponding Author: Professor Dr M Niaz Asadullah, \\ Faculty of Economics and Administration \\ University of Malaya, Malaysia. \\ Email:m.niaz@um.edu.my \\ Mobile: (+60) 163872667
}

\section{Author Bios:}

M Niaz Asadullah is a Professor of Development Economics at the Faculty of Economics and Administration, University of Malaya. He obtained a DPhil in Economics from the University of Oxford. He has held visiting positions at Harvard, Kent, Reading, BRAC, Manchester and Mindanao State Universities. His current research focuses on poverty, labor market and institutional development and has been supported by grants from Leverhulme Trust, AUSAID, DFID, International Growth Centre and the World Bank. Dr Asadullah is an associate editor of the Journal of Human Development and Capabilities.

Email:m.niaz@um.edu.my

N N TARUN CHAKRAVORTY is a Professor of Economics at the Siberian Federal University, Russia. He did his M.S.S. in Economics from the University of Dhaka, MA Economics from the University of Leeds and $\mathrm{PhD}$ from the University of Bath. Previously he taught at Independent University Bangladesh and Stamford University Bangladesh. His research interests include growth, development, inequality, well-being, governance and corruption.

Email: nntarun.edu@gmail.com

Acknowledgement: We're grateful to Adam Kinnison, Antonio Savoia, Ajit Mishra and two anonymous referees of this journal for their valuable comments. The usual disclaimers apply. 


\title{
Growth, Governance and Corruption in Bangladesh: A Re-assessment
}

\begin{abstract}
This paper revisits Bangladesh's 'double paradox'- sustained macroeconomic growth despite the poor state of governance and a high level of corruption- by critically reviewing trends in governance and corruption indicators during 1990-2017 vis-à-vis other South Asian countries. In addition, we draw upon data from a purposefully designed survey of manufacturing firms to assess the state of economic governance in the export-oriented readymade garments (RMG) sector, the country's main source of foreign exchange and driver of economic growth. Consistent with the country's poor ranking in a host of indicators of investment climate and corruption perception, in-depth interviews of RMG factory owners confirm high cost of doing business in various forms. We also find no evidence of growthmediated improvements in indicators of governance. On the contrary, our review of print media reports also suggest a growing governance deficit in the country's financial sector. We conclude by discussing the implications of our findings for the country's future growth as well as performance of the RMG sector.
\end{abstract}

JEL Codes: D73; O16; O43

Key words: Bribe; Corruption; Economic Growth; Governance; Industrial Development. 


\section{Introduction}

The view that economic growth not only depends on investment and human capital but also requires conducive governance and institutional factors is well-recognized in the literature ${ }^{i}$. However, Bangladesh's recent economic performance challenges the view that good governance is a necessary condition for sustained economic growth. Corruption perception surveys consistently rank the country very poorly, behind most other South Asian countries ${ }^{\text {ii }}$. Recent public opinion polls on the corruption situation also confirm that citizens predominantly believe corruption and bribes to be restricting access to jobs, justice, healthcare, education and other public goods ${ }^{\mathrm{iii}}$ (International Republican Institute 2017). Yet, Bangladesh has sustained a relatively high growth rate despite its dysfunctional governance structure and political system. In the past, a handful of South Asian countries have also grown without large-scale improvements in corruption ranking ${ }^{\text {iv }}$. Corruption was pervasive alongside rapid economic growth in development states such as Japan and South Korea implying that it is not necessary to root out corruption first to spur growth. The experience of other East Asian countries (e.g. China) suggest a reverse causality i.e. initial economic growth can occur despite bureaucratic corruption, which in turn can facilitate improvement in at least some aspects of governance at a later stage of economic development ${ }^{\mathrm{v}}$. These experiences have reinforced the view that corruption and poor governance are not fundamental barriers to economic growth.

In the above context, this study re-examines the link between economic growth and corruption using Bangladesh as a case study. We do so by drawing upon secondary cross-country data as well as Bangladesh-specific primary survey data and media content analysis. The main objective is to assess whether there is any evidence of growth-mediated improvements in various aspects of economic governance, particularly corruption. We first summarize Bangladesh's recent growth performance and discuss trends in selected investment climate and corruption indicators vis.-a-vis. other regional competitors. A wide range of country-level subjective and objective indicators are used for this purpose. To complement this analysis, we present primary evidence on the cost of doing business in the country's most industrialized districts based on 92 in-depth interviews conducted during 2011-2012. Our respondents are firm owners and/or managers in Bangladesh's export-oriented ready-made garments (RMG) sector, the main engine of industrial growth of the economy. By investigating the country's main export sector, we provide descriptive evidence on the growth-corruption relationship based on survey-based firm-level analysis of the incidence of bribes. Lastly, we analyse media reports on corruption and financial irregularities to validate the analysis of country-level and sector-specific corruption.

The two key contributions of our study are to (i) add to the international debate on the effect of growth on corruption and (ii) present new evidence on the effects of corruption from a sectorspecific analysis. Combating corruption and improving governance is key to achieving the Sustainable Development Goals (SDGs) while the SDG target 16.5 is to "substantially reduce corruption and bribery in all their forms" by 2030. According to the United Nations' introduction to SDG 16, corruption, bribery, tax evasion and related illicit financial flows deprive developing countries of around US\$1.26 trillion per annum ${ }^{\mathrm{vi}}$. Curbing corruption is, therefore, an end objective in itself - important regardless of its impact on growth.

The rest of the paper is organized as follows. Section 2 briefly summarizes Bangladesh's recent growth performance. Section 3 reviews the existing literature on corruption and economic performance emphasizing that we do not know enough on whether, and how, economic development should alleviate corruption. Section 4 reviews the trends in indicators such as 
time required to start a business, cost to start a business, strength of governance structure index, ease of doing business index and corruption perception index in Bangladesh vis-a-vis other South Asian countries. Section 5 presents survey evidence from the RMG sector on the cost of doing business. Section 6 discusses the findings additionally drawing upon a media content analysis while section 7 concludes.

\section{Background: Bangladesh's Growth Trends}

At the end of the Millennium Development Goals era, Bangladesh has outranked many other developing countries of a similar income level in poverty and human development statistics including its economically advanced neighbors such as India and Pakistan. Gender and health indicators improved significantly by the early 2000s and the trend was sustained in later years. The improvement was significantly higher compared to economies sharing similar levels of income. So striking has been this achievement that many have called it a "development surprise"vii. A collaborative development strategy involving various non-government organizations (NGOs) was instrumental to the social progress achieved through a combination of low-cost solutions, gender-targeted programs and social awareness campaigns. A vibrant NGO sector for social services delivery also helped Bangladesh to bypass the prevailing "governance deficit" in the public sector. Contextual factors such as high population density facilitated the easy adoption of low-cost solutions and the quick spread of good practices. Political commitments to social development also ensured policy continuity across various political regimes viii. The progress in human and social development during 1990s and 2000s produced a positive feedback effect on the economy, facilitating the country's graduation into the lower middle-income category. This transition however primarily benefited from rising agricultural productivity, export of ready-made garments, and foreign remittances from migrant workers, which all combined to produce a "growth surprise"ix .

The annual economic growth has averaged around more than $6 \%$ over the past decade and has surpassed that of Pakistan, even though the former started from a much lower position in economic, developmental and social indicators with an economy devastated by the Pakistani army during the war of independence ${ }^{\mathrm{x}}$ and 'emerging as an independent nation after a bloody liberation war with Pakistan in 1971, the new country lacked basic infrastructure and institution' ${ }^{x i}$. The industrial sector in Bangladesh (the erstwhile East Pakistan) accounted for 6\%-7\% of its GDP while that in West Pakistan accounted for over 20\% xii. By 2016, industries contributed $28.77 \%$ of the GDP in Bangladesh while the figure for Pakistan, India and the South Asian average were 19.36\%, 28.85\% and 27.8\% respectively. Recently, Bangladesh has surpassed Pakistan in terms of GDP per head in US dollars converted at the market exchange rates. In 2017 Bangladesh had \$1,538 per head while Pakistan had about $\$ 1,470^{\text {xiii }}$. In 2016 GDP per capita (constant LCU) when converted into US\$ of the exchange rate of June 30 of the same year the figures for Bangladesh and Pakistan appear to be 709.14 and 581.41 respectively.

\section{[Figure 1 about here]}

Figure 1 plots data on GDP growth rates of the South Asian countries over 1990-2017. Bangladesh has been growing around the South Asian average in terms of GDP growth rate. Barring a few years, it has been consistently above other regional competitors such as Pakistan. Over 1990-2017, 1990-2003 and 2004-2017 Bangladesh's average GDP growth rate was $5.49 \%, 4.7 \%$ and $6.16 \%$ while Pakistan's figures over the respective periods were $4.14 \%$, $3.86 \%$ and $4.45 \%$ and South Asian averages were 6.27\%, 5.28\%, 7.27\%. In an earlier 
assessment, the World Bank (2003) applauded the country's GDP per capita growth rate of 3.3 percent per year in the 1990s; it was three times faster than the average for low-income countries during the 1990s. But the World Bank report also observed that further progress needed improvement in governance and the corruption situation. Yet, Bangladesh grew at an even faster rate in the following years. A more recent assessment predicts that Bangladesh's growth resilience is likely to continue ${ }^{\mathrm{xiv}}$.

One of the key drivers of Bangladesh's resilient macroeconomic performance is the 'explosive growth' of the RMG sector ${ }^{\mathrm{Xv}}$. A unique institutional arrangement such as Export-processing Zones (EPZs) helped bypass governance deficits in the industrial sector in the early years. After 2009, Bangladesh overtook India as the leading RMG exporter in South Asia (Figure 2). Despite political instability and deterioration of law and order, total exports during FY2011-13 increased significantly and this has been primarily driven by the RMG sector (Figure 2). The RMG industry now accounts for 75 percent of the country's export earnings and 25 percent of $\mathrm{GDP}^{\mathrm{xvi}}$. Moreover, it employs more than three million out of the 70 million workforce. Female employment in the sector has also positively impacted human development ${ }^{\text {xvii }}$, which, in turn, is likely to have strengthened the process of economic growth.

\section{[Figure 2 about here]}

The next section offers a brief review of the literature on the importance of good governance to better understand Bangladesh's puzzling macroeconomic growth trends.

\section{Growth-Governance Nexus: Review of the literature}

Studies on the determinants of economic growth in Bangladesh have emphasized the importance of governance-related factors such as corruption. Ahluwalia and Mahmud (2004) and Devarajan (2005) cautioned that the country's public service delivery system was corrupt and it would hinder industrial growth. According to Zafarullah and Siddiquee (2001), bureaucratic corruption and inefficiency is causing billions of dollars' worth of loss in Bangladesh in terms of unrealized investment and income. Mahmud and Mahajan (2010) found strong evidence of growth being negatively affected by the adverse governance factors, viz. corrupt behaviour of government officials. Similar concerns were also shared by earlier studies. Mauro (1995, p.683) conjectured that "if Bangladesh were to improve the integrity and efficiency of its bureaucracy by a one-standard-deviation increase in the bureaucratic efficiency index, its yearly GDP growth rate would rise by over half a percentage point." According to an estimate of the World Bank (2000b), per-capita income in Bangladesh could increase two-fold in absence of corruption. More recent estimates by the World Bank suggest that reducing corruption in Bangladesh to the level prevailing in Scandinavian countries could add 2.1 to $2.9 \%$ to its annual per capita GDP growth ${ }^{\text {xviii }}$.

The above concerns are supported by the available theoretical and empirical literature on the cross-country variation in economic growth which also suggests a strong positive causal effect running from better governance to higher per capita incomes ${ }^{\text {xix }}$. Some studies have examined the effect of the components of the composite governance indicator, World Governance Indicators (WGI), separately on economic growth and reach the same conclusion ${ }^{\mathrm{xx}}$. Among other important studies, De Groot, Linders, Rietveld, and Subramanian (2004) found regulatory quality to have a positive effect on both trade and economic growth in democratic countries while Jalilian, Kirkpatrick, and Parker (2006) suggested a significant positive impact of 
regulatory quality and government effectiveness (two components of WGI) on the GDP per capita in developing countries.

Turning to research specific to the role of corruption, some studies specifically looked into the effect of bribes on economic growth and reported no evidence in favour of the 'sand the wheel hypothesis'. For instance, Méon and Weill (2010) find evidence of 'grease the wheel hypothesis', which appears to be more prominent in countries with a weaker institutional framework or poor governance. But others (e.g. Freund, Hallward-Driemeier, and Rijkers, 2015) rejected the 'grease the wheel hypothesis' and found a strong negative association between bribe demands and firm growth. More recent meta-analyses of the existing studies on corruption, however, confirm a negative impact on growth ${ }^{\mathrm{xxi}}$.

The extant literature also acknowledges a two-way relationship between growth and corruption. A sustained spell of economic growth can improve governance in the long-run ${ }^{\text {xxii }}$. Equally, it is possible that over time, countries may be growing out of corruption. Indeed, many East Asian developmental states experienced the "double paradox" of growth surge during a period of high levels of political corruption ${ }^{x x i i i}$. The process of economic growth over time reduced both the incentives for government officials to extract bribes and firms' willingness to pay them. According to the 'life cycle' theory proposed in Ramirez (2014), the growthcorruption nexus follows an inverse U-shaped path whereby corruption peaks at early stages of economic development and declines as countries industrialize. However, research on the opposite causal relationship - the effect of economic growth on corruption-is limited (for a recent survey of the literature, look to the study mentioned below $\left.{ }^{\text {xxiv }}\right)$. Moreover, the growthcorruption nexus may differ depending on the type of corruption (e.g. petty corruption or small bribes that households have to pay to access public services; grand corruption such as large bribes to secure government procurement; in-kind bribes for elite politicians).

The literature review in this section, therefore, raises three important questions: First, is the corruption scenario in Bangladesh improving despite the country's poor rating in CPI? Second, is bribery also common in the country's leading manufacturing sector? Third, are bribes in the RMG sector a case of 'greasing the wheel' or do they pose a major barrier in the form of the cost of doing business? We discuss these issues in the next section. We single out corruption because unlike other governance indicators, it is easy to quantify and can be verified independently without necessarily relying on perception data. Besides, we show that in contrast to the concensus on the negative effect of corruption on economic growth in the literature, disaggregate analysis of other governance indicators often produce inconclusive results. ${ }^{\mathrm{xxv}}$

\section{Trends in corruption perception and the cost of doing business: Bangladesh vs South Asian countries}

Despite steady economic growth and graduation to the lower middle-income bracket, the country is ranked poorly in corruption perceptions surveys (Table 1). Compared to 2015, its rank improved slightly in Transparency International's corruption perception Index (CPI) in 2017 but slipped in 2018, leaving it ranked 13th from the bottom. As a matter of fact, despite favourable social indicators, it even ranked behind South Asian countries such as Bhutan, India, the Maldives, Nepal, Pakistan and Sri Lanka. ${ }^{x x v i}$ This is also confirmed by the low rank in the WJP Rule of Law Index (World Justice Project 2018). ${ }^{\text {xvii }}$

\section{[Table 1 about here]}


Bangladesh's ranking in corruption perception is consistent with recent trends in the indicators of investment climate such as time and the financial cost to start a new business (Table 2). The cost to start a business in Bangladesh is one of the highest in South Asia. While the cost has fallen sharply between 2005 and 2016, indicating some improvements in the governance situation, the rate of decline has been higher for other countries such as India. Moreover, the figures for Bangladesh still remain below the South Asian average in 2016. The number of days required to start a business in Bangladesh in 2016 was the second highest (19 days) in South Asia.

\section{[Table 2 about here]}

Trends in two other indicators, namely 'ease of doing business' and 'strength of governance structure' show a similar pattern. In terms of 'ease of doing business', Bangladesh ranks almost at the bottom in South Asia. Bangladesh is only 7 points above Afghanistan (Table 2). In all other South Asian countries, doing business is easier than in Bangladesh indicating that poor governance directly impacts on industrial performance. ${ }^{\text {xxviii }}$

Bangladesh's ranking in CPI is also partly shaped by the reality that corruption control has remained static in the last five years. Table 2 doesn't capture the cost of doing business, which is perceived to be high. Apart from bribery-related added costs, irregularities in the financial sector are a major concern. During the last five years, political control of commercial banks has increased. In 2015, the central bank of Bangladesh provided \$20 million to garments manufacturers and exporters under 'Export Development Fund (EDF)' scheme, much larger than past allocations. The Central Bank also cut the interest rate for 270 sick garment companies to $8 \%$ from $15 \%$, and of $8 \%$, the government paid $3 \%$ as a subsidy in $2011^{\mathrm{xxix}}$. At the same time, several state-run Banks illegally lent large sums of money to little-known RMG and non-RMG companies on fake documents. The accumulated default bank loans stood at US\$142.03b (BDT 111, 347 crores) as of April 2016, compared to US\$50.74b (BDT 35,000 crores) in early $2009^{\mathrm{xxx}}$. Mutual Evaluation Report (MER) of APG concluded that governance failings and appointment of politically linked people to the boards of public banks breed corruption promoting money laundering, financial crime risks for loan default, frequent scams and poor recovery of stolen money, scam, fraud and embezzlement ${ }^{\mathrm{xxxi}}$.

\section{Corruption and the cost of doing business: Survey evidence from the RMG sector}

The irregularities in the banking sector and the hidden cost of business financing aside, entrepreneurs in Bangladesh face significant costs to business in the form of bribes paid. The government has been dismissive of the country's poor CPI rating as it is based on subjective assessment. Therefore, in this section, we review survey evidence of bribe-related corruption using objective data.

The World Bank's Bangladesh Enterprise Survey Unit collected data for the period 2008-2010 by interviewing representative samples of the formal, non-agricultural, non-extractive, private sector firms, with a view to gathering information about what businesses and firms experience. The respondents of the Enterprise Survey are mainly the business owners and top managers. Based on the World Bank enterprise Survey data, the size of bribes in Bangladesh is below the average for South Asia (USD1946 vs. USD2148).

[Figure 3 about here] 
How serious is the problem in Bangladesh's leading export sector? Estimates of bribes based on WBES are conservative since the sample also doesn't include sufficient numbers of RMG factories. Therefore, we conducted 92 in-depth interviews of firm owners and managers in Bangladesh's RMG sector. RMG firms were selected through a combination of stratified and multi-stage clustered sampling methods.

The main findings are presented in Table 3. First, $22.8 \%$ of the respondents reported bribes as the most important barrier, while 3.3\% held extortion as the most important barrier. Second, $49 \%$ named either bribes or extortion as a retarding factor, and the percentage of respondents which consider bribes as a retarding factor for firm growth is $49 \%$ as well. Third, businessmen offer bribes for their own benefit (e.g. to avoid tax or duty; under-invoicing an imported item and so on). Fourth, there are established norms regarding how much to be paid as bribes in import and export activities which are usually fixed by the customs officials. Fifth, foreign companies also bribe government officials. To get a contract from the Bangladesh government to supply some machinery, a foreign company has to pay 2.8 million US dollars to each of the five concerned ministries. In other words, both foreign and local companies have accepted the 'custom' of bribe payments.

Through our survey, we were able to elicit from the firm owners and managers the following important information which is line with the World Bank Survey data but more detailed explicitly revealing the ground realities. To form an import/export oriented joint stock company government fees range from US\$857 to US\$1428.58 depending on how many departments are required to approve the registration/ license are needed and the type of activities the company engages in. But our survey reveals that before starting the business one has to spend US $\$ 34,332$ on average, which is one of the highest figures in the world. The number of days taken by government offices for the following are: for trade license 26 days, for company registration 95 days, board of investment registration 83 days, export import license 51 days, utilization permission 65 days, gas connection 161 days, electric connection 97 days, water line 36 days, telephone line 35 days, permission from the environment department 79 days, fire license 27 days, bond license 53 days. In response to the indirect question about bribe payments 'Many businessmen have informed us that they had to spend money outside that needed in formal procedures. How much do you think one belonging to your industry/sector and of the similar size as yours has to spend in this way in a year?' on average the respondents estimate the amount to be US\$23,330. In 2009-10 the amount of informal payments for the regular operation of the firms is US $\$ 14,808$.

For firms already in operation, the number of days taken to get things done with some government departments is as follows: 20 days to clear goods through customs; 9 days to get clear payments from the AG office; 17 days to obtain a tax certificate; 11 days to obtain a VAT certificate and 13 days to renew the fire license. Unsurprisingly, $92.39 \%$ of the firms expressed their dissatisfaction with the quality of four essential public services which are gas supply, electricity supply, water supply and telephone (Table 3).

Bribes have been fairly systematic in exporting industries like garments. In both in-depth interviews and from the survey interviews the following information has been collected. Based on the sample average figures, bribery in this sector is systematic. For exports, a firm has to spend $0.75 \%$ of its turn-over and for imports $0.4 \%$ of its turn-over on the services from a Clearing and Forwarding $(\mathrm{CnF})$ agent. A typical firm exporting and/or importing goods in this sector has to pay on average US\$20986.73 a year for the services provided by CnF agents. Customs officials used to be paid a bribe of between US $\$ 42.86$ and US\$57.14 for 'utilization 
permission' while bribes paid to BGMEA officials for the same document ranged between US\$2.86 and US\$4.29. ${ }^{\text {xxii }}$ To avoid such complications in official procedures, sample firms spend a sizable amount on accounting firms and solicitors, on average spending US $\$ 18464.73$ a year (Table 3 ).

\section{[Table 3 about here]}

In sum, regardless of whether we look at the size and prevalence of unauthorized payments, bribes constitute a significant cost of business in Bangladesh's main manufacturing sector. In the next section, we investigate whether corruption and economic mis-governance is a systemwide problem or whether it is specific to the country's manufacturing sector. We do so by reviewing media coverage on cases of financial sector scams and irregularities in the past 5 years.

\section{Discussion}

At the initial stage of the RMG sector development, a wide range of subsidies and concessions combined with preferential access to foreign markets helped bypass the governance problems that held back industrial growth in other sectors. ${ }^{\text {xxiii }}$ As the country's industrial structure becomes more complex through diversification to non-RMG exports, further expansion will critically depend on a more favourable investment climate. In this section we present evidence, based on media reports published in recent years, to document the extent of bribes, fund embezzlements and/or unofficial payments in the economy and the nature of governance challenges in the financial and non-financial sectors. This is then followed by a discussion of earlier results on the prevalence of bribery in the country's RMG sector.

Table 4 below summarizes key incidents of embezzlements of public funds, financial irregularities and illegal capital flight. Consistent with our survey findings on RMG firms, serious cases of bribery, as widely reported in the Bangladeshi media, are rampant in recruitment, transfer and promotion in public sector. Table 4 summarizes major cases reported by the largest English Daily in Bangladesh. The first panel reports bribes paid to government officials (in non-business context) while the third panel summarizes media reports on bribes paid to revenue and customs department officials alongside notable cases of tax and duty avoidance/evasion. The second panel summarizes major cases of illegal capital flight/money laundering covered in the media. The estimates/figures are either based on TIB or official figures reported by government agencies.

As seen from table 4 (panel (a)), the amount of bribes paid in the public sector for staff recruitments range between US\$3,866 and US\$5,154. Much larger bribes are required in the case of transfer of administrative officers (US\$9,665 on average) and transfer/posting of doctors (between US\$1,610 and US\$1,933). The prevalence of bribes in industrial sectors coincide with an overall decline in financial governance standards in the country as is evidenced from media reports on high profile cases of illegal outflow and embezzlement of public funds (Table 4 (panel (c)). On average, illicit outflows eat away 1.1 percent of the country's gross domestic product each year, which is also equivalent to 12.7 percent of the country's total tax revenue. ${ }^{\text {xxiv }}$ Institutional corruption is also rampant in imports controls by government bodies such as National Board of Revenue (NBR) and customs officials. According to one estimate, Bangladesh is missing out over US\$145.7 million in revenue a year as the PSI (pre-shipment inspection) firms are bribed to achieve under- or over-invoicing, false 
inspection and certification of consignments. Exploitation of the privilege of duty-free imports, violation of bonded warehouse licencing rules and duty evasion is rampant in Bangladesh.

\section{[Table 4 about here]}

The evidence presented on financial mis-governance and irregularities including bribes in Tables 3 and 4 is perplexing. The country's export-oriented RMG sector prospered during the 1990s apparently rejecting the view that good governance is a necessary pre-condition for industrial growth. However, much of this manufacturing growth was driven by enclave-type arrangements that helped the export-oriented garment industry to bypass the governance constraints. The resultant economic growth, driven by the country's rapidly expanding RMG sector, did not lead to visible improvements in investment climate. Bangladesh has ranked consistently poorly in global assessment of governance and corruption ratings during 20002015. The quality of public institutions also did not improve significantly by international standards. This implies the absence of a "virtuous circle" in the case of Bangladesh whereby higher incomes have not led to further improvements in governance. The causal effect did not run from per capita incomes to corruption either in case of Bangladesh. ${ }^{\mathrm{xxx}}$

Another perspective that is relevant to the growth-corruption debate in the context of Bangladesh is the role of political institutions. Some studies report a nonlinear relationshipat a low level of economic development, as they find, a growth in per capita income could increase corruption, but after a threshold level of income, an increase in income is seen to lower corruption $^{\mathrm{xxxvi}}$. In case of Bangladesh, such non-linear effect is also absent. One causal channel for the effect of corruption on growth is the quality of democracy or the degree of freedom or civil rights of the citizens ${ }^{\mathrm{xxxvii}}$. Democracy helps reduce corruption and thus exerts a positive effect on growth. Yet, sustained economic growth in the country did not see improvement in democratic institutions. Although Bangladesh has enjoyed democratically elected governments since 1990, the corruption perception index did not show a significant fall over the past two decades. Only during 1996 to 2001 Bangladesh was ranked above the bottom quintile in some governance indicators as there was a perception in that period that democratic system seemed to be working with successive regime changes taking place through peaceful credible elections. Since then, Bangladesh's governance rankings have been steadily deteriorating ${ }^{\text {xxxviii }}$. The institutions which are to maintain checks and balances in a democratic state have become heavily politicised. In that sense, the political state of Bangladesh is, in fact a "false democracy". This contrasts with East Asian non-communist countries such as Singapore, that have sustained macroeconomic growth under the authoritarian rule while also curbing corruption and improving bureaucratic efficiency ${ }^{\text {xxix }}$. Corruption did subside as the Singaporean economy grew but this also coincided with significant anti-corruption efforts. Corruption in Bangladesh, on the other hand, has become degenerative and entrenched among party and government officials.

How should we interpret the RMG-sector specific corruption? According to Ahmed et al (2014 p. 262), 'stable and predictable corruption is simply a fact of doing business in the industry' which implies a systematic and 'benign' bribery system. But corrupt officials may influence the law-making body and make regulations with a view to extracting bribes in future ${ }^{\mathrm{xl}}$. In this context, bribery could be the consequence of the extensive state support to the RMG sector. Many of Bangladesh's 300 parliamentarians directly own garment factories or have financial interests in the garments industry and have colluded with the state to suppress factory wages ${ }^{\text {xli }}$. Part of the state money could be redistributed back to the bureaucrats as payments for institutional support and preferential treatments. These issues are left for future research. 


\section{Conclusion}

Based on data collected from the country's most prominent export-oriented industrial clusters through in-depth interviews of factory owners, we have presented fresh evidence on the high private cost of doing business in Bangladesh. Regardless of whether the actual impact of corruption is 'positive' or 'negative' on the Bangladesh economy, our study confirms that the perceived level and reported cases of corruption continue to be the norm. High-profile cases of embezzlement of public funds from state-owned institutions undermine business confidence, increase the cost of doing business and sustain the culture of bribe seeking by public officials.

What are the main lessons from Bangladesh's "double paradox" of rapid growth and rising corruption? In the past, macroeconomic growth benefited from the rapid expansion of the RMG sector which prospered through a combination of preferential market access and FDI-led production carried out in EPZs. However, moving forward, the country faces stiff regional competition to sustain its manufacturing exports. The Bangladesh economy also needs a higher growth rate to sustain its journey on the middle income path and to become a high income nation by 2040. This critically hinges on an investment-led strategy that focuses on productivity and innovation and is aided by efficient public institutions. Future growth of the country's GDP will also depend on rapid expansion of its export oriented RMG sector. The importance of investment-focused and export-led policies have also been recognized in government policy documents ${ }^{\text {xlii }}$. However, policies are rarely implemented and, based on the evidence provided in this paper, there's little indication of progress in economic governance and corruption control. Inability to fight bureaucratic corruption at all levels of the government, particularly in the industrial sector, will make further expansion harder as manufacturing industries shift to higher value added activities and technological upgrading. As noted by Myrdal (1968) in Santhanam Committee Report nearly five decades ago, the so-called 'speed money' may avoid delays for an individual but it increases red-tapism as part of the culture in the country, slowing down the whole economy in the end. In this connection, lowering the cost of doing business will not only facilitate rapid expansion of the private sector, it will also help meet the SDGs target of "responsive, inclusive, participatory and representative decision-making at all levels". 


\section{References}

Ahluwalia, I.J. \& Mahmud, W.. "Economic transformation and social development in Bangladesh." Economic and Political Weekly, pp. 4009-4011 (2004).

Ahmed, Faisal Z, Anne Greenleaf, and Audrey Sacks. "The paradox of export growth in areas of weak governance: The case of the ready-made garment sector in Bangladesh." World Development 56:258-71 (2014).

Aidt, T.S. "Corruption, institutions, and economic development." Oxford Review of Economic Policy 25(2): 271-291 (2009).

Aidt, T., Dutta, J. \& Sena, V. "Governance regimes, corruption and growth: Theory and evidence." Journal of Comparative Economics 36(2) (2008):195-220.

Ang, Yuen Yuen. How China Escaped the Poverty Trap. Cornell University Press (2016).

Asadullah, M Niaz. "Educational Disparity in East and West Pakistan, 1947-71: Was East Pakistan Discriminated Against?” The Bangladesh Development Studies:1-46 (2010).

Asadullah, M Niaz, Antonio Savoia and Wahiduddin Mahmud. "Paths to Development: Is There a Bangladesh Surprise?" World Development. 62, 138-154 (2014).

Ben Ali, M.S., and S. Saha. "Corruption and economic development." Pp. 133-54 in Economic Development in the Middle East and North Africa: Challenges and Prospects edited by M. S. Ben Ali. New York Palgrave Macmillan (2016).

Butkiewicz, James L, and Halit Yanikkaya. "Institutional quality and economic growth: Maintenance of the rule of law or democratic institutions, or both?" Economic Modelling 23(4) (2006):648-61.

Chowdhury, S.K. "The effect of democracy and press freedom on corruption: an empirical test." Economics letters, 85(1) (2004) :93-101.

De Groot, H.L., Linders, G.J., Rietveld, P. and Subramanian, U. "The institutional determinants of bilateral trade patterns." Kyklos, 57(1) (2004): pp.103-123.

De Long, J. Bradford, and Andrei Shleifer. "Princes and merchants: European city growth before the industrial revolution." The Journal of Law and Economics 36, no. 2 (1993): 671702.

Devarajan, S. "South Asian Surprises.” Economic and Political Weekly 40 (37) (2005): 40134015

Devarajan, Shantayanan, and Simon Johnson. "Two comments on "Governance indicators: where are we, where should we be going?" by Daniel Kaufmann and Aart Kraay." The World Bank Research Observer 23, no. 1 (2008): 31-36. 
Djezou, Wadjamsse B. "The democracy and economic growth nexus: empirical evidence from cote d'Ivoire." The European Journal of Comparative Economics 11(2) (2014):251.

Drury, A.C., Krieckhaus, J. \& Lusztig, M. "Corruption, democracy, and economic growth." International Political Science Review 27(2) (2006):121-136.

Dimant, Eugen, and Guglielmo Tosato. "Causes and effects of corruption: what has past decade's empirical research taught us? A survey." Journal of Economic Surveys 32, no. 2 (2018): 335-356.

Easterly, W. and Levine, R.. "Tropics, germs, and crops: how endowments influence economic development." Journal of monetary economics 50(1) (2003):3-39.

Freund, Caroline, Mary Hallward-Driemeier, and Bob Rijkers. "Deals and Delays: Firm-Level Evidence on Corruption and Policy Implementation Times." The World Bank Economic Review 30(2) (2015):354-82.

Global Financial Integrity, Illicit Financial Flows to and from 148 Developing Countries: 20062015 (2019).

Gerring, J., Thacker, S.C. and Alfaro, R. "Democracy and human development." The Journal of Politics 74(1) (2012):1-17.

Hossain, Naomi. The Aid Lab. Oxford University Press, 2017.

Hanlon, Joseph, Roy, Manoj and Hulme, David. Bangladesh Confronts Climate Change. Anthem Press, 2016.

Heath, Rachel \& Mushfiq Mobarak, A. "Manufacturing growth and the lives of Bangladeshi women," Journal of Development Economics, 115(C) (2015):1-15.

Huang, Chiung-Ju, and Yuan-Hong Ho. "Governance and economic growth in Asia." North American Journal of Economics and Finance (39) (2017):260-72.

International Republican Institute. "Bangladesh: Daily Challenges: Public Opinion on Economics, Politics and Security." Washington, DC, 2017.

Jalilian, Hossein, Colin Kirkpatrick, and David Parker. "2. Creating the conditions for international business expansion: the impact of regulation on economic growth in developing countries-a cross-country analysis." Regulating Development: Evidence from Africa and Latin America (2006): 11.

Kaufmann, D. \& Wei, S.-J. Does grease money speed up the wheels of commerce? The World Bank, 1999.

Kraay, Aart, Pablo Zoido-Lobaton, and Daniel Kaufmann. Aggregating governance indicators. The World Bank, 1999.

Knack, S. \& Keefer, P. "Institutions and economic performance: cross- country tests using alternative institutional measures." Economics \& Politics 7(3) (1995):207-227. 
Ko, Kilkon, and Weng, C. Structural changes in Chinese corruption. China Quarterly, 211 (2012): 718-740.

La Porta, R., Lopez-de-Silanes, F., Shleifer, A. \& Vishny, R. "The quality of government." Journal of Law, Economics, and organization 15(1) (1999): 222-279.

Lewis, D. "Crossing the boundaries between 'Third Sector' and state: Life-work histories from the Philippines, Bangladesh and the UK." Third World Quarterly 29(1) (2008):125-141.

Mahmud, W., Growth and Governance: Making the Transition, Paper presented at the Bangladesh Economists' Forum (BEF) conference, 21-22 June, 2014.

Mahmud, W. \& Mahajan, S. "Economic Reforms, Growth and Governance: The Political Economy Aspects of Bangladesh's Development Surprise.” In: David Brady \& M. Spence, eds. Leadership and Growth. Washington D.C.: World Bank, 2010.

Mahmud, Wahiduddin, Asadullah, M. Niaz, and Antonio Savoia."Bangladesh's Achievements in Social Development Indicators: Explaining the Puzzle." Economic and Political Weekly (2013):XLVIII(44).

Mauro, P. "Corruption and Growth." Quarterly Journal of Economics 110(3) (1995):681-712.

Méon, Pierre-Guillaume, and Laurent Weill. "Is corruption an efficient grease?" World Development 38(3) (2010):244-59.

Myrdal, Gunnar. Asian drama; an inquiry into the poverty of nations. Vol. 1. Pantheon, 1972.

Nawaz, Saima. "Growth effects of institutions: A disaggregated analysis." Economic Modelling 45 (2015):118-26.

Neusiedl, C.. "The deep marketisation of development in Bangladesh." Third World Quarterly, 38(7) (2017):1639-1654.

North, D. “Growth and structural change.” New York: Norton, 1981.

Rahman, Md. Ashiqur. "Governance matters: climate change, corruption, and livelihoods in Bangladesh," Climatic Change, vol. 147(1) ((2018)) :313-326.

Rigobon, R. and Rodrik, D. "Rule of law, democracy, openness, and income." Economics of Transition 13(3) (2005): 533-564.

Rivera- Batiz, F.L. "Democracy, governance, and economic growth: theory and evidence." Review of Development Economics 6(2) (2002):225-247.

Shleifer, A. \& Vishny, R.W. "Politicians and firms." The Quarterly Journal of Economics (1994): 995-1025. 
Sonobe, Tetsushi, Khondoker Abdul Mottaleb, and Md Nurul Amin. "The Miraculous Development of the Garment and Pharmaceutical Industries in Bangladesh." In Economic and Social Development of Bangladesh, pp. 27-51. Palgrave Macmillan, Cham, 2018.

The Daily Star, 2007. "NBR fines PSI Cotecna for under invoicing luxury autos" Nov 05, 2007. http://www.thedailystar.net/news-detail-10404

The Daily Star, 2008. "Graft goes institutional amid lax NBR watch" May 22, 2008. http://www.thedailystar.net/news-detail-37618

The Daily Star, 2009. "Koko charged with money laundering" November 12, 2009. http://www.thedailystar.net/news-detail-113862

The Daily Star, 2011. "ACC investigation continues" Sept 03, 2011. http://www.thedailystar.net/news-detail-200903

The Daily Star, 2012. "Hallmark loan scam under ACC probe" August 14, 2012. http://www.thedailystar.net/news-detail-246119

The Daily Star, 2014. "Bribe for everything" November 07, 2014. http://www.thedailystar.net/bribe-for-everything-49143

The Daily Star, 2015a. “Export fund raised to \$2b" May 28, 2015.

https://www.thedailystar.net/business/export/export-fund-raised-2b-88372

The Daily Star, 2015b. "Money laundering cases on the rise" August 23, 2015.

http://www.thedailystar.net/business/money-laundering-cases-the-rise-131080

The Daily Star, 2016. "Apparel exporter sued for money laundering" June 16, 2016. http://www.thedailystar.net/country/apparel-exporter-sued-money-laundering-1240303

The Daily Star, 2017a. "Public Bank Scams: Problems left to persist" July 16, 2017. https://www.thedailystar.net/frontpage/public-bank-corruption-in-bangladesh-problems-leftpersist-1433755

The Daily Star, 2017b. "Bribery at every step" December 01, 2017.

https://www.thedailystar.net/frontpage/bribery-every-step-1498822

The Daily Star, 2017c. “AB Bank laundered Tk 165cr to UAE” Dec 18, 2017.

http://www.thedailystar.net/frontpage/bb-probe-reveals-ab-bank-scam-1506478

The Daily Star, 2018. "Customs files Tk 120cr case against Mastex for duty evasion"

Jan 03， 2018. http://www.thedailystar.net/business/customs-files-tk-120cr-case-againstmastex-duty-evasion-1514137

The Economist, 2017. "Bangladesh's GDP per person is now higher than Pakistan's" September 07, 2017.

World Bank, 2000b. Corruption in Bangladesh- Costs and Cures. Dhaka: W. Bank. 
World Bank, 2003. "Bangladesh's achievements: Further progress requires better governance". Coventry. Washington D.C.: World Bank.

World Bank, 2017. "Bangladesh Development Update: Breaking Barriers”. Washington D.C.: World Bank.

World Bank. 2017. World Development Indicators 2017. Washington D.C.: World Bank..

World Bank, BANGLADESH DEVELOPMENT UPDATE: Building on resilience, 2018.

Ramirez, Carlos D. "Is corruption in China "out of control"?" A comparison with the US in historical perspective," Journal of Comparative Economics, 42(1), (2014):76-91.

Transparency International, 2017. "Corruption Perception Index 2017". February 21, 2018. https://www.transparency.org/news/feature/corruption_perceptions_index_2017

Ugur, M. "Corruption's Direct Effects on Per- Capita Income Growth: A Meta- Analysis." Journal of Economic Surveys, 28(3) (2014) :472-490.

Wedeman, A. Double paradox: Rapid growth and rising corruption in China. Ithaca, N.Y.: Cornell University Press (2012).

World Justice Project, 2018. The WJP Rule of Law Index 2017-2018. https://worldjusticeproject.org/sites/default/files/documents/WJP-ROLI-2018-June-OnlineEdition_0.pdf (accessed: 12 Feb 2019)

Zafarullah, H. \& Siddiquee, N.A. "Dissecting public sector corruption in Bangladesh: issues and problems of control." Public Organization Review, 1(4)(2001) :465-486. 
Figure 1: GDP growth rate of South Asian countries, 1990-2017

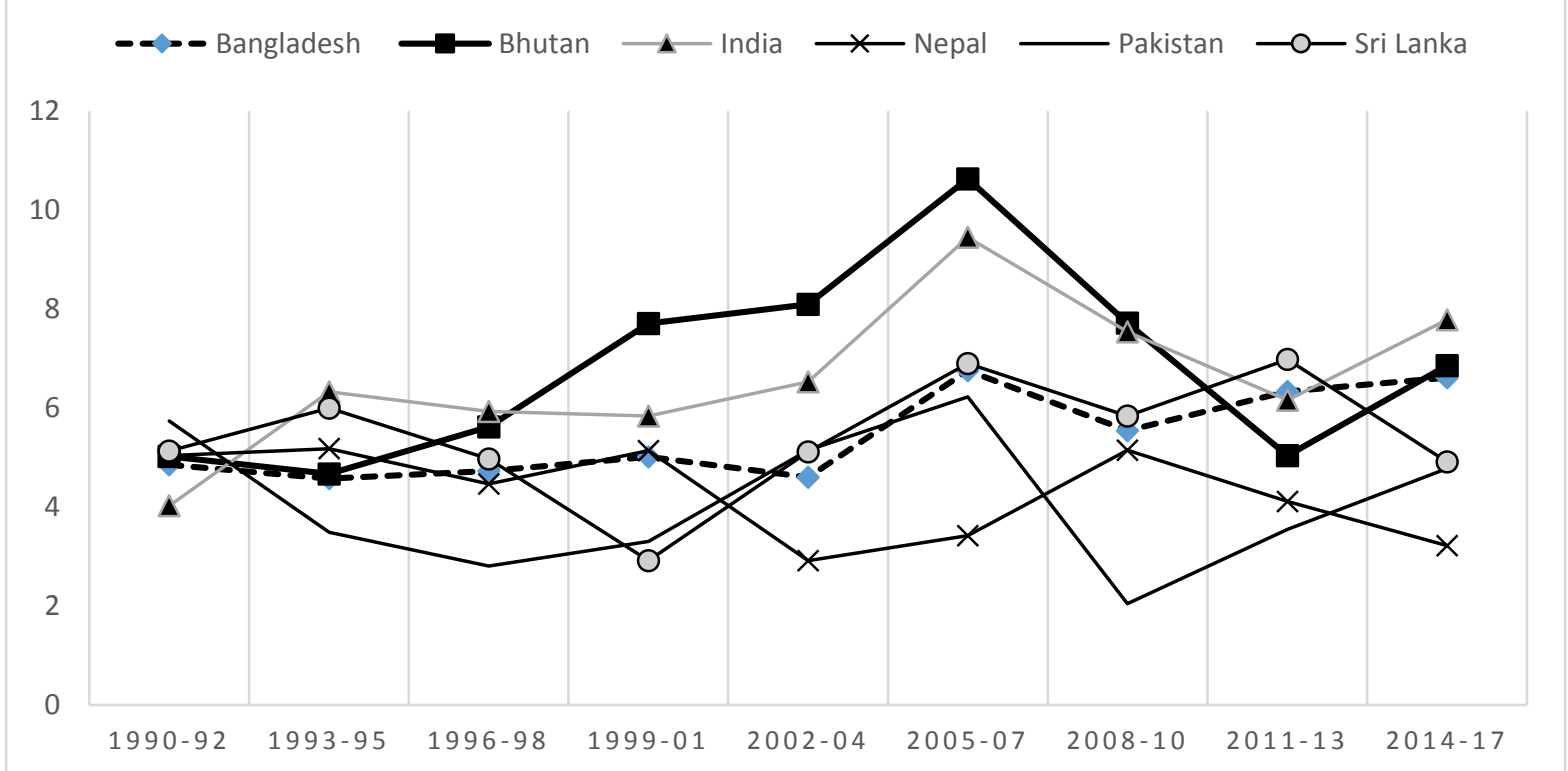

Source: World Bank Development Indicators (2017), World Bank. Note: GDP growth (annual \%) refers to "annual percentage growth rate of GDP at market prices based on constant local currency" on constant 2010 U.S. dollars. 
Figure 2: Trends in Garment Export Volume from Bangladesh and Selected South Asian Countries, 1992-2016 (in USD millions)

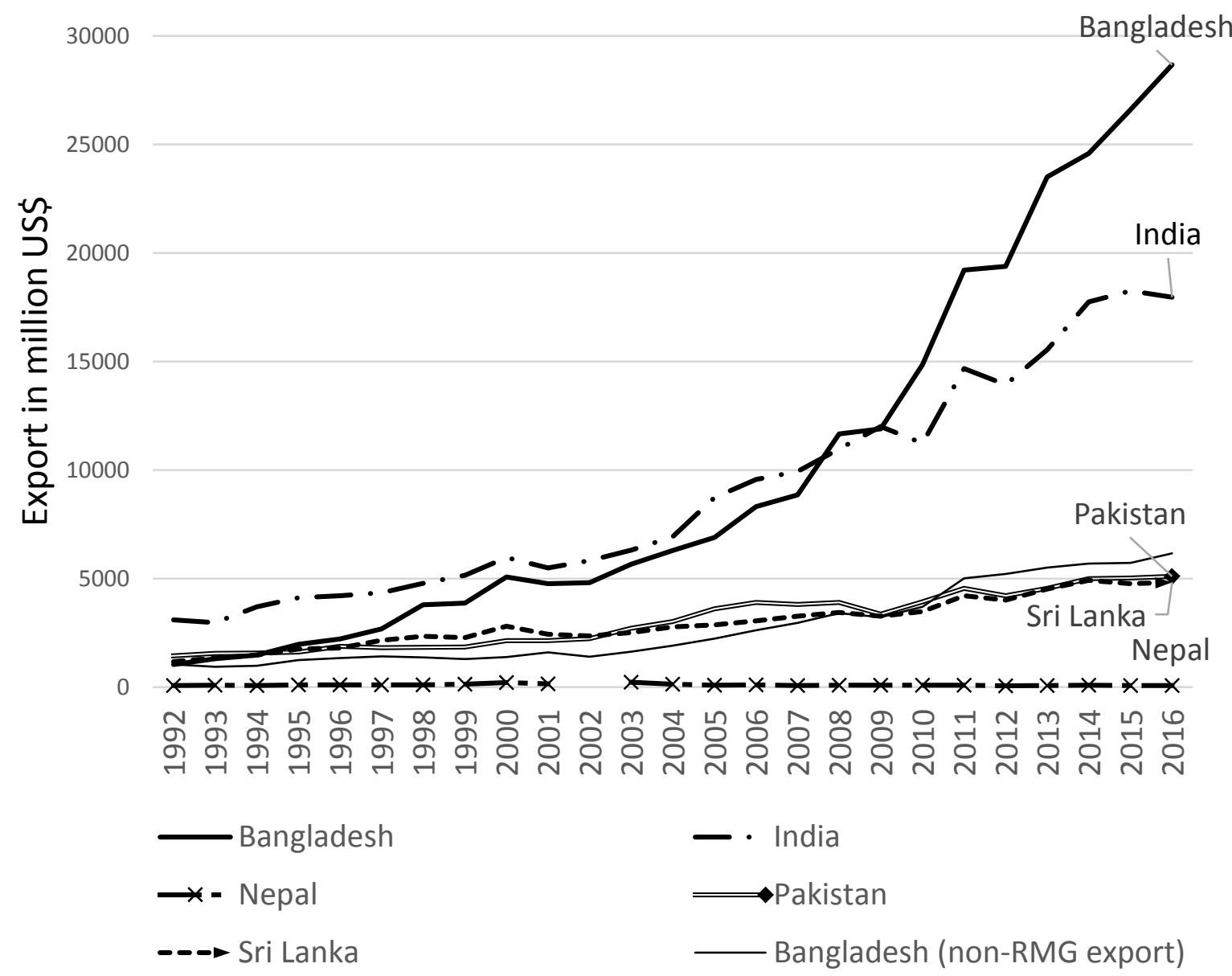

Data source: World Trade Organization, 2018, "Statistics database" (accessed 04 Oct 2018).

Notes: (1) Afghanistan and Bhutan do not export RMG while no data is available on Maldives after 2005; so these 3 countries are excluded. (2) RMG export refers to clothing export under the category of merchandise trade as provided by World Trade Organization. (3) For country-specific comparison purpose, non-RMG export volume is reported only for Bangladesh. 
Figure 3: Amount of bribes paid to government offices in South Asia in 2017 (US\$)

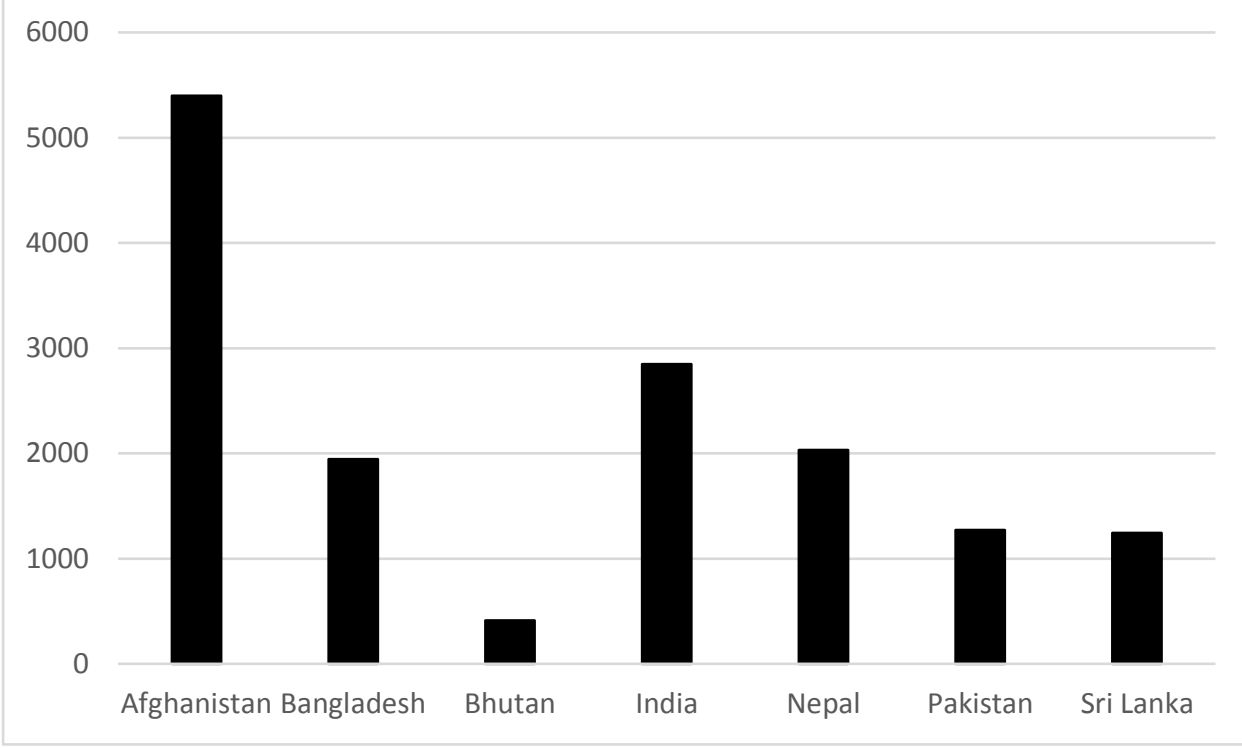

Data source: World Bank Enterprise Survey (WBES), World Bank, 2017. Notes: (a) Figures are country averages. (b) In WBES, data on bribes is collected based on responses to the question: 'It is said that establishments are sometimes required to make gifts or informal payments to public officials to "get things done" with regard to customs, taxes, licenses, regulations, services etc. On average, what estimated total annual value, do establishments like this one pay in informal payments or gifts to public officials for this purpose?' 
Table 1. Trends in Corruption Perception Index (CPI) in South Asian countries, 2007-2017

\begin{tabular}{|c|c|c|c|c|c|c|c|c|c|}
\hline & AFG & BGD & IND & PAK & LKA & MDV & NPL & BTN & SA \\
\hline 2007 & $\begin{array}{l}1.8 \\
(172)\end{array}$ & $\begin{array}{c}2 \\
(162)\end{array}$ & $\begin{array}{c}3.5 \\
(72)\end{array}$ & $\begin{array}{c}2.4 \\
(138)\end{array}$ & $\begin{array}{c}3.2 \\
(94)\end{array}$ & $\begin{array}{c}3.3 \\
(84)\end{array}$ & $\begin{array}{c}2.5 \\
(131)\end{array}$ & $\begin{array}{c}5 \\
(46)\end{array}$ & $\begin{array}{c}2.96 \\
(112)\end{array}$ \\
\hline 2008 & $\begin{array}{l}1.5 \\
(176)\end{array}$ & $\begin{array}{c}2.1 \\
(147)\end{array}$ & $\begin{array}{c}3.4 \\
(85)\end{array}$ & $\begin{array}{c}2.5 \\
(134)\end{array}$ & $\begin{array}{c}3.2 \\
(92)\end{array}$ & $\begin{array}{c}2.8 \\
(115)\end{array}$ & $\begin{array}{c}2.7 \\
(121)\end{array}$ & $\begin{array}{c}5.2 \\
(45)\end{array}$ & $\begin{array}{c}2.93 \\
(114)\end{array}$ \\
\hline 2009 & $\begin{array}{l}1.3 \\
(179)\end{array}$ & $\begin{array}{c}2.4 \\
(139)\end{array}$ & $\begin{array}{c}3.4 \\
(84)\end{array}$ & $\begin{array}{c}2.4 \\
(139)\end{array}$ & $\begin{array}{c}3.1 \\
(97)\end{array}$ & $\begin{array}{c}2.5 \\
(130)\end{array}$ & $\begin{array}{c}2.3 \\
(143)\end{array}$ & $\begin{array}{c}5 \\
(49)\end{array}$ & $\begin{array}{c}2.8 \\
(120)\end{array}$ \\
\hline 2010 & $\begin{array}{l}1.4 \\
(176)\end{array}$ & $\begin{array}{c}2.4 \\
(134)\end{array}$ & $\begin{array}{c}3.3 \\
(87)\end{array}$ & $\begin{array}{c}2.3 \\
(143)\end{array}$ & $\begin{array}{c}3.2 \\
(91)\end{array}$ & $\begin{array}{c}2.3 \\
(143)\end{array}$ & $\begin{array}{c}2.2 \\
(146)\end{array}$ & $\begin{array}{c}5.7 \\
(36)\end{array}$ & $\begin{array}{c}2.85 \\
(120)\end{array}$ \\
\hline 2011 & $\begin{array}{l}1.5 \\
(180)\end{array}$ & $\begin{array}{c}2.7 \\
(120)\end{array}$ & $\begin{array}{l}3.1 \\
(95)\end{array}$ & $\begin{array}{c}2.5 \\
(134)\end{array}$ & $\begin{array}{c}3.3 \\
(86)\end{array}$ & $\begin{array}{c}2.5 \\
(134)\end{array}$ & $\begin{array}{c}2.2 \\
(154)\end{array}$ & $\begin{array}{c}5.7 \\
(38)\end{array}$ & $\begin{array}{c}2.94 \\
(118)\end{array}$ \\
\hline 2012 & $\begin{array}{l}0.8 \\
(174)\end{array}$ & $\begin{array}{c}2.6 \\
(144)\end{array}$ & $\begin{array}{c}3.6 \\
(94)\end{array}$ & $\begin{array}{c}2.7 \\
(139)\end{array}$ & $\begin{array}{c}4 \\
(79)\end{array}$ & N/A & $\begin{array}{c}2.7 \\
(139)\end{array}$ & $\begin{array}{c}6.3 \\
(33)\end{array}$ & $\begin{array}{c}3.24 \\
(115)\end{array}$ \\
\hline 2013 & $\begin{array}{l}0.8 \\
(175)\end{array}$ & $\begin{array}{c}2.7 \\
(136)\end{array}$ & $\begin{array}{c}3.6 \\
(94)\end{array}$ & $\begin{array}{c}2.8 \\
(127)\end{array}$ & $\begin{array}{l}3.7 \\
(91)\end{array}$ & N/A & $\begin{array}{c}3.1 \\
(116)\end{array}$ & $\begin{array}{c}6.3 \\
(31)\end{array}$ & $\begin{array}{c}3.29 \\
(106)\end{array}$ \\
\hline 2014 & $\begin{array}{l}1.2 \\
(172)\end{array}$ & $\begin{array}{c}2.5 \\
(145)\end{array}$ & $\begin{array}{c}3.8 \\
(85)\end{array}$ & $\begin{array}{c}2.9 \\
(126)\end{array}$ & $\begin{array}{c}3.8 \\
(85)\end{array}$ & N/A & $\begin{array}{c}2.9 \\
(126)\end{array}$ & $\begin{array}{c}6.5 \\
(30)\end{array}$ & $\begin{array}{c}3.37 \\
(110)\end{array}$ \\
\hline 2015 & $\begin{array}{l}1.1 \\
(166)\end{array}$ & $\begin{array}{c}2.5 \\
(139)\end{array}$ & $\begin{array}{c}3.8 \\
(76)\end{array}$ & $\begin{array}{c}3 \\
(117)\end{array}$ & $\begin{array}{c}3.7 \\
(83)\end{array}$ & N/A & $\begin{array}{c}2.7 \\
(130)\end{array}$ & $\begin{array}{l}6.5 \\
(27)\end{array}$ & $\begin{array}{c}3.33 \\
(105)\end{array}$ \\
\hline 2016 & $\begin{array}{l}1.5 \\
(169)\end{array}$ & $\begin{array}{c}2.6 \\
(145)\end{array}$ & $\begin{array}{c}4 \\
(79)\end{array}$ & $\begin{array}{c}3.2 \\
(116)\end{array}$ & $\begin{array}{c}3.6 \\
(95)\end{array}$ & $\begin{array}{c}3.6 \\
(95)\end{array}$ & $\begin{array}{c}2.9 \\
(131)\end{array}$ & $\begin{array}{l}6.5 \\
(27)\end{array}$ & $\begin{array}{c}3.49 \\
(107)\end{array}$ \\
\hline 2017 & $\begin{array}{l}1.5 \\
(177)\end{array}$ & $\begin{array}{c}2.8 \\
(143)\end{array}$ & $\begin{array}{c}4 \\
(81)\end{array}$ & $\begin{array}{c}3.2 \\
(117)\end{array}$ & $\begin{array}{l}3.8 \\
(91)\end{array}$ & $\begin{array}{c}3.3 \\
(112)\end{array}$ & $\begin{array}{c}3.1 \\
(122)\end{array}$ & $\begin{array}{l}6.7 \\
(26)\end{array}$ & $\begin{array}{c}3.55 \\
(109)\end{array}$ \\
\hline
\end{tabular}

Source: Corruption Perception Index (2017), Transparency International. Notes: (1) Figure in parenthesis is country rank. (2) Transparency International started constructing CPI for different countries in different years; for South Asia, all the countries appear in CPI in 2007. That's why, we have presented data on CPI from 2007.

Table 2. Trends in selected investment climate indicators in South Asian countries, 2005-2016

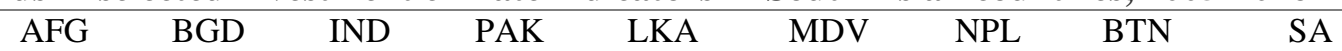

\begin{tabular}{|c|c|c|c|c|c|c|c|c|c|}
\hline \multicolumn{10}{|c|}{ A. Time required to start business (number of days) ${ }^{a}$} \\
\hline 2005 & 9 & 51.5 & 93 & 23 & 46 & 9 & 31 & 62 & 40.6 \\
\hline 2006 & 9 & 43.5 & 36 & 25 & 46 & 9 & 31 & 62 & 32.7 \\
\hline 2007 & 9 & 67.5 & 34 & 24 & 42 & 9 & 31 & 48 & 33.1 \\
\hline 2008 & 9 & 66.5 & 32 & 24 & 44 & 9 & 31 & 46 & 32.7 \\
\hline 2009 & 7 & 43.5 & 32 & 20 & 44 & 12 & 31 & 46 & 29.4 \\
\hline 2010 & 7 & 26.5 & 30 & 20 & 38 & 12 & 31 & 46 & 26.3 \\
\hline 2011 & 7 & 26.5 & 30 & 19 & 35 & 12 & 29 & 35 & 24.2 \\
\hline 2012 & 7 & 26.5 & 28 & 19 & 11 & 12 & 29 & 35 & 20.9 \\
\hline 2013 & 5 & 21.8 & 31.2 & 19 & 11 & 12 & 17 & 30 & 18.4 \\
\hline 2014 & 7 & 19.5 & 33.5 & 19 & 11 & 12 & 17 & 15 & 16.8 \\
\hline 2015 & 7 & 19.5 & 28 & 19 & 10 & 12 & 17 & 15 & 15.9 \\
\hline 2016 & 7 & 19.5 & 26 & 18 & 9 & 12 & 17 & 15 & 15.4 \\
\hline
\end{tabular}

B. Cost to start a business (\% of income per capita) ${ }^{b}$ 


\begin{tabular}{rrrrrrrrrr}
\hline 2005 & 75.2 & 56.1 & 62 & 25.6 & 50 & 14 & 69.9 & 16.9 & 46.2 \\
\hline 2006 & 67.4 & 52.1 & 78.4 & 22.8 & 43.7 & 14 & 78.5 & 14.1 & 46.4 \\
\hline 2007 & 84.6 & 46.2 & 74.6 & 15.3 & 19.7 & 13.4 & 73.9 & 8.8 & 42.1 \\
\hline 2008 & 59.5 & 25.5 & 70.1 & 13.7 & 47 & 11.5 & 60.2 & 7.2 & 36.8 \\
\hline 2009 & 30.2 & 28.6 & 66.1 & 16 & 41.9 & 10 & 53.6 & 6.8 & 31.7 \\
\hline 2010 & 26.7 & 21.2 & 50.5 & 17.8 & 33.9 & 9.4 & 46.6 & 6.1 & 26.5 \\
\hline 2011 & 25.8 & 19.5 & 42 & 17.7 & 30.1 & 8.9 & 37.4 & 6.1 & 23.4 \\
\hline 2012 & 22.5 & 19.6 & 43.1 & 16.1 & 26.6 & 6 & 33 & 6 & 21.6 \\
\hline 2013 & 14.4 & 18.8 & 41.2 & 15.9 & 26.1 & 6.2 & 34.6 & 4.8 & 20.3 \\
\hline 2014 & 15.1 & 16.8 & 16.2 & 14.6 & 20.7 & 6.2 & 32.2 & 4.2 & 15.8 \\
\hline 2015 & 19 & 13.9 & 14.3 & 13.9 & 18.7 & 4.9 & 28.4 & 4 & 14.6 \\
\hline 2016 & 19.9 & 13.8 & 13.8 & 12.4 & 12.2 & 5.2 & 26.1 & 3.8 & 13.4 \\
\hline
\end{tabular}

\begin{tabular}{cccccccccc}
\hline C. & \multicolumn{1}{c}{ Strength of governance structure index $\mathbf{( 0 - 1 0 . 5 )} \mathbf{c}^{\mathbf{c}}$} \\
\hline 2013 & 0.7 & 5 & 7.3 & 7.3 & 6 & 3.7 & 6.3 & 5 & 5.2 \\
\hline 2014 & 0.7 & 5 & 8 & 7.3 & 6 & 3.7 & 6.3 & 5 & 5.3 \\
\hline 2015 & 0.7 & 5 & 8 & 7.3 & 6 & 3.7 & 6.3 & 5 & 5.3 \\
\hline 2016 & 0.7 & 5 & 8 & 7.3 & 6 & 3.7 & 6.3 & 5 & 5.3
\end{tabular}

D. Ease of doing business index (1=easiest to $185=$ most difficult $)^{d}$

\begin{tabular}{llllllllll}
2015 & 182 & 178 & 131 & 148 & 109 & 129 & 100 & 71 & 131 \\
\hline 2016 & 183 & 176 & 130 & 144 & 110 & 135 & 107 & 73 & 132.3
\end{tabular}

Source: a, b, c, d World Bank Development Indicators, Doing Business Project (2017), The World Bank 
Table 3: Survey estimates of days taken to access government services and the size of bribes in the RMG sector

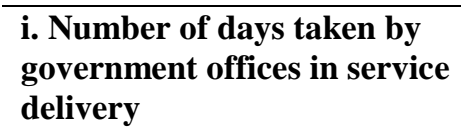

\section{ii. Amount of bribes paid}

\begin{tabular}{lc}
\hline Type of services & No. of days taken \\
\hline Gas connection & 161 \\
Electricity connection & 97 \\
Company registration & 95 \\
Registration with Board of Investment & 83 \\
Environment department & 79 \\
Utilization permission & 65 \\
Bond license & 53 \\
Import-Import license & 51 \\
Water line & 36 \\
Telephone line & 35 \\
Fire license & 27 \\
Trade license & 26 \\
Customs clearance & 20 \\
Tax certificate & 17 \\
Fire license renew & 13 \\
VAT certificate & 11 \\
Clearance from AG office & 9
\end{tabular}

\begin{tabular}{lc}
\hline Purpose & Bribes in US\$ \\
\hline Formation of a company & $34332^{\mathrm{a}}$ \\
Total informal pay & $23330^{\mathrm{a}}$ \\
During operation & $14808^{\mathrm{a}}$ \\
For export, per invoice & $5.71^{\mathrm{b}}$ \\
For import, per consignment & $142.86^{\mathrm{b}}$ \\
For CA/law firm & $18464.73^{\mathrm{b}}$ \\
For Clearing and Forwarding Agent $(\mathrm{CnF})$ & $22422^{\mathrm{b}}$ \\
\hline
\end{tabular}

Source: Authors' survey. Official fees required to form a company ranges between US $\$ 857$ and US $\$ 1428.58$. (a) refers to amount actually paid while (b) refers to the amount others are perceived to pay by other firms in the RMG sector. All estimates are based on data for the period 2008-2011. 
Table 4. Media content analysis of bribery, corruption and financial irregularities in Bangladesh

Types of corruption/areas of corruption $\quad$ Amounts (US\$) Time period

Panel (a): Bribes in government departments

Recruitments of ad hoc doctors on average ${ }^{1}$

Recruitments of 3rd and 4th class employees

Transfer of admin officers to the capital and adjacent districts ${ }^{1}$

5,154

2014

Transfer of doctors from remote areas to the capital

3,866

2014

Transfer of doctors from remote areas to municipality areas or from

9,665

2014

one regional town to another ${ }^{1}$

1,933

2014

Recruitment, transfers or promotions in case of general government jobs. ${ }^{1}$

$1,610 \quad 2014$

$6,508 \quad 2014$

\begin{tabular}{lll}
\hline Panel (b): Illegal capital flight/money laundering & \\
\hline Amounts of money laundered (case-1) $^{2}$ & 2.98 million & $2003-2007$ \\
Amounts of money laundered (case-2) $^{3}$ & 0.14 million & By 2011 \\
Amounts of money laundered (case-3) $^{4}$ & 0.25 million & 2009 \\
Amounts of money laundered (case-4) $^{5}$ & 0.013 million & 2009 \\
Amounts of money laundered (case-5) $^{6}$ & 1.99 million & $2002-2007$ \\
Amounts of money laundered (case-6) $^{7}$ & 0.93 million & $2002-2007$ \\
Total amount funnelled out on average per year $^{8}$ & 1.31 billion & $2003-2012$ \\
Bangladeshi citizens' deposits with various Swiss banks $^{9}$ & 551.97 million & 2014 \\
Bangladeshi citizens' deposits with various Swiss banks $^{10}$ & 406.35 million & 2013 \\
Bangladeshi citizens' deposits with various Swiss banks $^{11}$ & 243.44 million & 2012 \\
Anecdote: Money laundering by a single bank & & 2014 \\
& 43.87 million & 2013 \\
\hline
\end{tabular}

Panel (c): Bribery in NBR and Customs, tax and duty avoidance/evasion

As the PSI (pre-shipment inspection) companies allow under- or

145.7 million

(2008-) Per year

over-invoicing, false inspection and certification of consignments

Bangladesh is missing out over ${ }^{14}$

Loss of revenue by NBR due to under- or over- invoicing, false

179.65 million

Till Feb 2007 inspection and certification of consignments by importers and exporters amounted to ${ }^{15}$

Anecdote1: One RMG firm shipped 297 apparel consignments abroad but did not bring back any proceeds from the exports. and thus has siphoned off about ${ }^{16}$

Anecdote2: One PSI company certified an import consignment with 0.034 million

2007

price tags of $\$ 18,500$ per vehicle while the actual price was

$\$ 35,215$. Thus, through under-invoicing it helped the importer evade tax of ${ }^{17}$

Anecdote3: One company violated bonded warehouse licencing rules and evaded ${ }^{18}$

14.51 million

2017

(iv) financial irregularities

\begin{tabular}{lll}
\hline $\begin{array}{l}\text { The amount embezzled from public banks by six little known } \\
\text { commercial entities }^{\mathrm{i}}\end{array}$ & 4.34 billion & As of Aug 2012 \\
\hline Default bank loans (cumulative value) $^{\mathrm{ii}}$ & 142.03 billion & As of April 2016 \\
\hline $\begin{array}{l}\text { Default bank loans (cumulative value) } \\
\text { iii }\end{array}$ & 50.74 billion & As of early 2009 \\
\hline $\begin{array}{l}\text { The amount embezzled from public banks by six little known } \\
\text { commercial entities }\end{array}$ & 4.34 billion & As of Aug 2012 \\
\hline
\end{tabular}

Source: See Appendix A. 
${ }^{i}$ De Long, J. Bradford, and Andrei Shleifer. "Princes and merchants: European city growth before the industrial
revolution." The Journal of Law and Economics 36, no. 2 (1993): 671-702; Knack, S. \& Keefer, P. "Institutions and economic performance: cross- country tests using alternative institutional measures." Economics \& Politics 7(3) (1995):207-227; La Porta, R., Lopez-de-Silanes, F., Shleifer, A. \& Vishny, R. "The quality of government.” Journal of Law, Economics, and organization 15(1) (1999): 222-279.

ii Transparency International, 2017. "Corruption Perception Index 2017". February 21, 2018. https://www.transparency.org/news/feature/corruption_perceptions_index_2017.

iii International Republican Institute. "Bangladesh: Daily Challenges: Public Opinion on Economics, Politics and Security." Washington, DC, 2017.

iv Devarajan, S. "South Asian Surprises.” Economic and Political Weekly 40 (37) (2005): 4013-4015; Devarajan, Shantayanan, and Simon Johnson. "Two comments on "Governance indicators: where are we, where should we be going?" by Daniel Kaufmann and Aart Kraay." The World Bank Research Observer 23, no. 1 (2008): 31-36.

${ }^{v}$ Ang, Yuen Yuen. How China Escaped the Poverty Trap. Cornell University Press (2016).

${ }^{\text {vi }}$ https://www.un.org/sustainabledevelopment/peace-justice/

vii Mahmud, Wahiduddin, Asadullah, M. Niaz, and Antonio Savoia."Bangladesh's Achievements in Social Development Indicators: Explaining the Puzzle." Economic and Political Weekly (2013):XLVIII(44); Hossain, Naomi. The Aid Lab. Oxford University Press, 2017.

viii Asadullah, M Niaz, Antonio Savoia and Wahiduddin Mahmud. "Paths to Development: Is There a Bangladesh Surprise?" World Development. 62, 138-154 (2014).

${ }^{\text {ix }}$ World Bank, BANGLADESH DEVELOPMENT UPDATE: Building on resilience, 2018.

x The Economist, 2017. "Bangladesh's GDP per person is now higher than Pakistan's" September 07, 2017.

xi Lewis, D. 'Crossing the boundaries between 'Third Sector' and state: Life-work histories from the Philippines, Bangladesh and the UK.” Third World Quarterly 29(1) (2008):125-141.

xii Asadullah, M Niaz. "Educational Disparity in East and West Pakistan, 1947-71: Was East Pakistan Discriminated Against?” The Bangladesh Development Studies:1-46 (2010).

xiii The Economist, 2017. "Bangladesh's GDP per person is now higher than Pakistan's" September 07, 2017.

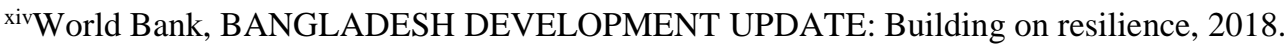

${ }^{x v}$ Hossain, Naomi. The Aid Lab. Oxford University Press, 2017.

${ }^{\text {xvi }}$ Ahmed, Faisal Z, Anne Greenleaf, and Audrey Sacks. "The paradox of export growth in areas of weak governance: The case of the ready-made garment sector in Bangladesh.” World Development 56:258-71 (2014).

${ }^{\text {xvii }}$ Heath, Rachel \& Mushfiq Mobarak, A. "Manufacturing growth and the lives of Bangladeshi women," Journal of Development Economics, 115(C) (2015):1-15; Sonobe, Tetsushi, Khondoker Abdul Mottaleb, and Md Nurul Amin. "The Miraculous Development of the Garment and Pharmaceutical Industries in Bangladesh." In Economic and Social Development of Bangladesh, pp. 27-51. Palgrave Macmillan, Cham, 2018.

xviii Rahman, Md. Ashiqur. "Governance matters: climate change, corruption, and livelihoods in Bangladesh," Climatic Change, vol. 147(1) ((2018)) :313-326.

xix a North, D. "Growth and structural change.” New York: Norton, 1981; Butkiewicz, James L, and Halit Yanikkaya. "Institutional quality and economic growth: Maintenance of the rule of law or democratic institutions, or both?" Economic Modelling 23(4) (2006):648-61; Djezou, Wadjamsse B. "The democracy and economic growth nexus: empirical evidence from cote d'Ivoire." The European Journal of Comparative 
Economics 11(2) (2014):251; Easterly, W. and Levine, R.. “Tropics, germs, and crops: how endowments influence economic development." Journal of monetary economics 50(1) (2003):3-39; Kraay, Aart, Pablo Zoido-Lobaton, and Daniel Kaufmann. Aggregating governance indicators. The World Bank, 1999; Aidt, T.S. "Corruption, institutions, and economic development." Oxford Review of Economic Policy 25(2): 271-291 (2009).

xixb Kaufmann, Kraay, and Zoido (1999) find a clear positive effect of good governance on economic growth. Easterly and Levine (2003) also report a positive governance effect on per capita income.

${ }^{x x}$ Rigobon, R. and Rodrik, D. "Rule of law, democracy, openness, and income." Economics of Transition 13(3) (2005): 533-564.

xxi Ugur, M. “Corruption's Direct Effects on Per- Capita Income Growth: A Meta- Analysis.” Journal of Economic Surveys, 28(3) (2014) :472-490.

xxii Huang, Chiung-Ju, and Yuan-Hong Ho. "Governance and economic growth in Asia." North American Journal of Economics and Finance (39) (2017):260-72.

xxiii Wedeman, A. Double paradox: Rapid growth and rising corruption in China. Ithaca, N.Y.: Cornell University Press (2012).

xxiv Two exceptions are Aidt et al. (2008) and Bai et al. (2017). According to Aidt et al., growth-corruption relationship is non-linear. Given strong institutions, growth reduces corruption, but has no effect when institutions are weak. Using data on firms between 2006 and 2010 in Vietnam, Bai et al. found that higher levels of growth rates reduced corruption levels, in particular when there were strong land rights.

Dimant, Eugen, and Guglielmo Tosato. "Causes and effects of corruption: what has past decade's empirical research taught us? A survey." Journal of Economic Surveys 32, no. 2 (2018): 335-356.

${ }^{x x v}$ This is despite the fact that governance indicators such as rule of law are seen to lead to more significant economic growth in 'Not Free' countries when compared to 'Free' and 'Partly Free' countries (Huang and Ho 2017).

${ }^{\text {xxvi }}$ https://www.thedailystar.net/country/bangladesh-ranked-149-in-corruption-index-2018-1694437

xxvii Bangladesh is positioned 102nd among 113 countries in rule of law and 93rd in corruption related subcomponent.

xxviii This is also acknowledged by development partners e.g. the World Bank (2003) emphasizes that corruption increases the cost of doing business, saps public confidence in the investment climate and thus retards development.

xxix The Daily Star, 2015a. "Export fund raised to \$2b" May 28, 2015.

https://www.thedailystar.net/business/export/export-fund-raised-2b-88372

xxx The Daily Star, 2017a. "Public Bank Scams: Problems left to persist" July 16, 2017.

https://www.thedailystar.net/frontpage/public-bank-corruption-in-bangladesh-problems-left-persist-1433755

xxxi The Daily Star, 2017a. "Public Bank Scams: Problems left to persist" July 16, 2017.

https://www.thedailystar.net/frontpage/public-bank-corruption-in-bangladesh-problems-left-persist-1433755

xxxii Utilization permission is an official document, required to complete garments export procedure. It used to be issued by the customs authority. Because of the significant delays by the customs authority, the government authorized the Bangladesh Garments Manufacturers and Exporters Association (BGMEA) to issue this document.

xxxiii To facilitate export financing, the government (1986-87) in Bangladesh, instead of offering subsidies, introduced back-to-back letter of credit (L/C) system which did not require the garment manufacturers to open import L/C or make payment to the fabric suppliers from their own resources. This innovative system greatly minimized the problem of financing working capital for garment manufacturers (Ahmed, Greenleaf, and Sacks, 2014). 
xxiv This is also consistent with the evidence on the overall level of illicit capital outflow (defined as "money that is illegally earned, used or moved and which crosses an international border") from Bangladesh. According to Global Financial Integrity (2019), as much as US\$81.74 billion was siphoned off the country in 2006-2015.

xxxv Kaufmann and Kraay (2003) find the reverse causality to be negative and rules out such 'virtuous circles' i.e. automatic improvements in governance following a rise in per capita income.

xxxvi Ben Ali, M.S., and S. Saha. "Corruption and economic development." Pp. 133-54 in Economic Development in the Middle East and North Africa: Challenges and Prospects edited by M. S. Ben Ali. New York Palgrave Macmillan (2016).

xxxvii Drury, A.C., Krieckhaus, J. \& Lusztig, M. "Corruption, democracy, and economic growth.” International Political Science Review 27(2) (2006):121-136; Aidt, T., Dutta, J. \& Sena, V. “Governance regimes, corruption and growth: Theory and evidence." Journal of Comparative Economics 36(2) (2008):195-220; Chowdhury, S.K. "The effect of democracy and press freedom on corruption: an empirical test." Economics letters, 85(1) (2004) :93-101; Rivera- Batiz, F.L. "Democracy, governance, and economic growth: theory and evidence." Review of Development Economics 6(2) (2002):225-247; Nawaz, Saima. "Growth effects of institutions: A disaggregated analysis." Economic Modelling 45 (2015):118-26.

xxxviii Mahmud, W., Growth and Governance: Making the Transition, Paper presented at the Bangladesh Economists' Forum (BEF) conference, 21-22 June, 2014.

xxxix Gerring, J., Thacker, S.C. and Alfaro, R. "Democracy and human development." The Journal of Politics 74(1) (2012):1-17.

${ }^{x l}$ Shleifer, A. \& Vishny, R.W. "Politicians and firms.” The Quarterly Journal of Economics (1994): 995-1025; Kaufmann, D. \& Wei, S.-J. Does grease money speed up the wheels of commerce? The World Bank, 1999.

xliHossain, Naomi. The Aid Lab. Oxford University Press, 2017.

xlii Neusiedl, C.. "The deep marketisation of development in Bangladesh.” Third World Quarterly, 38(7) (2017):1639-1654. 